\title{
The Affecting Factors of Purchase Intention on Food and Beverage Products via Instagram for Millennials in Pandemic Situation
}

\author{
Author: Aditya Pratama ${ }^{1}$; Evelyne Gitania Novione ${ }^{2}$; Pingkan Sri \\ Ayu Rumengan ${ }^{3}$
}

\author{
Affiliation: Young Professional Business Management Program, Bina Nusantara University ${ }^{1}$; \\ Young Professional Business Management Program, Bina Nusantara University ${ }^{2}$; Young \\ Professional Business Management Program, Bina Nusantara University ${ }^{3}$
}

E-mail: Aditya_inc99@yahoo.com ${ }^{1}$; EvelyneEGN@yahoo.com ${ }^{2}$; Pingkanrumengan@gmail.com ${ }^{3}$ DOI $10.26821 /$ IJSRC.8.7.2020.8708>

\begin{abstract}
Problem - Food and beverage is now a highly developed business. Pandemic situations might change factors affecting purchase intention on food and beverage products through Instagram.

Purpose - Researchers want to find out whether there is a significant effect of celebrity endorsement, message, and e-WOM on purchase intention for food and beverage products through Instagram for millennials during the pandemic in the Jakarta area.

Design/methodology/approach - Post-test-only, randomly distributed, and data were collected by a questionnaire to 130 millennials respondents in Jakarta who had ever bought food and beverage products via Instagram.

Findings - The results showed that celebrity endorsement had a significant negative effect on purchase intention, while message and e-WOM had significant positive effect on purchase intention.

Research limitations/implications - This article provides information for further research on affecting factors of purchase intention in pandemic situations.

Practical implications - To increase purchase intention, companies need to take consideration of figures selection on celebrity endorsement, content of message, and e-WOM on Instagram.

Value - This article explains how celebrity endorsement, message and e-WOM affect purchase intention in this pandemic situation.
\end{abstract}

Keywords: Celebrity Endorsement, Message, eWOM, Purchase Intention, Pandemic Situation

\section{INTRODUCTION}

Nowadays, the internet is very important for supporting any activities especially for business purposes. Television and Radio have become very oldschool for people to find some information including food and beverage products while these days the internet simplifies the process so people can do anything at any time they need. People can do so much on the internet and social media.They can buy and sell some stuff online. The use of social media these days has an opportunity to be used as a trading platform (social commerce) in the food and beverage products especially in this pandemic situation when everyone is supposed to remain at home and online shopping using social media has become a new habit (Curty \& Zhang, 2012). In 2018, according to McKinsey social commerce has a big role to develop digital transaction activities and social commerce is also used as a link to all-digital services to reduce the cost of advertising services in conventional media before the rise of the use of e-commerce in Indonesia (Das, et al., 2018).

Social media provides new opportunities for marketers to be able to carry out marketing communications (Moriansyah, 2015). In Atmoko (2012), explained that Instagram is an application used to share photos through social networks taken by users, and add digital filters. Based on NapoleonCat which is a social media marketing analyst company in Warsaw, Poland reports that there were more than $61,610,000$ active Instagram Aditya Pratama; Evelyne Gitania Novione; Pingkan Sri Ayu Rumengan, Vol 8 Issue 7, pp 45-54 July 2020 
Volume 8 Issue 7 July 2020

users in Indonesia until the end of November 2019 and were dominated by those aged between 18-24 years (Putri, 2019). William Wongso said that of the many types of content found on Instagram, culinary is one of the most popular content for the people of Indonesia (Amadea, 2018). It was said in Wood (2019), that 69\% of millennials tend to take at least 1 photo of food during their visit to a restaurant or place to eat, then $30 \%$ prefer places that have an attractive appearance because places with an attractive appearance become their choice to be uploaded on their Instagram. By posting these photos, people will see and have an interest in buying. Currently, purchase intention continues to be a focus for businesses, one of which is in food and beverage products.

First factor related to purchase intention in this phenomenon is celebrity endorsement. According to Khan et al., (2016), the effect of celebrity endorsement to purchase intention is often discussed today and has become a phenomenon. With social media celebrities will be able to invite their fans to communicate more intensely (Khan, et al., 2016). This can be used as an opportunity for companies to carry out promotional activities considering that almost all groups are active users of social media (Khan et al., 2016). The second factor related to purchase intention in this phenomenon is the advertising message on the promotion itself whether verbal or nonverbal while promoting the product. In previous studies, it was explained that important messages must take precedence to attract consumers' buying interest and convince them of the products advertised by the company (Bovee, 1995; Sumartono, 2002; Hemamalini \& Kurup, 2014; Saleh, 2017). Next, the third is e-WOM. In the research of Zhang et al., (2016), it was mentioned that in decision making, the younger generation is active in the use of social media, it would be possible to share opinions through electronic word of mouth (e-WOM), both positively or negatively. In some previous studies it can be concluded that e-WOM has an important role that influences the attitudes and decisions of consumer purchases (Thurau, T et al., 2004; Permadi et al., 2014; Abubakar \& Ilkan, 2016).

Seeing the results of previous studies, there have been many studies that discuss the social media phenomenon that is associated with purchase intention. The model used to test this phenomenon such as the effect of e-WOM on purchase intentions discussed in the journal Sa'ait et al., (2016), the effect of celebrity endorsement on purchase intention in the scope of the mobile lin advertisement contained in the journal Khan (2018), the influence of celebrity endorsement on purchase intention in the scope of mobile advertisement discussed in the journal Abbas et al., (2018), the effect of e-WOM, brand image, and product knowledge on purchase intention in the journal Imbayani \& Gama (2018), as well as the phenomenon of the use of social media and the influence of peers on millennial generation on purchasing decisions written in the journal Wiridjati \& Roesman (2018). However, from the journals above, only discuss purchase intention in general, and not specifically research about food and beverage products on Instagram. Whereas in this day and age this is a phenomenon that is quite important to study, seeing food and beverage has a huge opportunity to be developed further in Indonesia. In addition, currently the condition of Covid-19 changes the situation of consumers about shopping. Lockdown and social distancing regulations require consumers to stay at home. This causes a change where the consumers cannot visit the offline store, so they have to go online to buy some stuff. So, further researeh needs to be done in the phenomenon of social media and purchase intentions in the food and beverage field at millennial generation through Instagram as one of popular social commerce applications for millennials, especially in this pandemic situation. Therefore, this article will discuss the phenomenon of social media in the food and beverage field in millennial generation through Instagram, by looking further at various factors related to purchase intention especially for this pandemic situation. This gives a big impact on business especially for food and beverage products, which is a highly developed business especially in this pandemic situation.

The purpose of this study is to identify the effect of celebrity endorsement, messages, and e-WOM on the purchase intention of food and beverage products through Instagram for millennials in Jakarta during a pandemic situation. In addition, this research can be used as material to add insight and knowledge related to the issue of celebrity endorsement, messages, eWOM, and purchase intention, especially for companies that want to market food and beverage products to millennials through Instagram, so for the future companies can determine better promotion strategies. 
Volume 8 Issue 7 July 2020

\section{THEORETICAL FRAMEWORK}

\subsection{Celebrity Endorsement}

Celebrity endorsement is every individual who gets public recognition and uses it to appear with a product in an advertisement (McCracken, 1989). This term is used and continues to be developed in subsequent purchase intention studies such as (Shimp, 2000; Patra \& Datta, 2010), and in 2014 by Karasiewicz \& Kowalczuk celebrity endorsements are defined as people known to the public because of actions or achievements that have been carried out in any form. This definition of celebrity endorsement is used in this study. In using celebrity endorsements, celebrities and brands must be able to represent information and associate consumers' memories of the product (Dewi, 2017). Both of these have a relationship in the endorsement process. Endorsers are individuals and characters who act as sources of information to convey messages (Mowen et al., 2002).

Rossister \& Percy (1998) explained that the main characteristics of celebrity endorsement can be assessed from personality, likeability, experience, credibility, and attractiveness. With a good assessment of these five things raises an interest in celebrity endorsers as well as physical characteristics as-well. The appeal will make the public have a good opinion about the celebrity endorser. Will be an added value for celebrity endorsers if the ads that are starred are in accordance with their characteristics (Mubarok, 2016). Pringle \& Binet (2005) explain that celebrity endorsers have an effective effect on an advertisement because it generates purchase intentions. By using celebrity figures on social media they have the opportunity to increase relation on their own social media, but can also advertise at the same time on the celebrity's social media with greater reach in approaching new potential customers (Schluschen, 2016).

It is said in Mubarok (2016) that using celebrity endorsement which has good characteristics can influence positive attitudes or consumer responses to endorsed products, so consumers have consideration in the buying process and can indirectly influence consumer behavior through the subconscious. After being affected unconsciously, consumers who want and will be interested in the product, will have the desire to buy, in the end will make a purchase of the desired product in the future. This statement is also in accordance with the results of research contained in the journals Juliana et al., (2018), which said that celebrity endorsers have a significant influence on purchase intention. In addition, written in Abbas et al., (2018), that celebrity endorsement is important and increases purchase intention.

This study discusses the effect of celebrity endorsement, messages, and e-WOM on food and beverage purchase intentions on Instagram in the millennial generation. This has also been examined by (Mubarok, 2016; Juliana et al., 2018, Abbas et al., 2018), but there are slight differences on the variables, the focus of the type of product, and the advertising media used. Then the similarity between this article and the journals above is on the research target of the millennial generation, and the use of celebrity endorsements. By looking at the results of previous studies regarding the effect of celebrity endorsement on purchase intention, the hypothesis 1 of this study is H1: Celebrity endorsement has a significant positive effect on purchase intention

\subsection{Message}

Advertising messages are news delivered to listeners or Aviewers through advertising media (Bovee, 1995). Advertising message is something that has been planned by the company so that it can be accepted by its listeners both verbally and nonverbally (Sumartono, 2002). Saleh (2017) explains that in the preparation of advertisements, there are a number of things that need attention, which are contents of message, message structure, message format, and message source.

According to Hemamalini \& Kurup (2014), along with technological developments, advertising messages from various sources and communication media are increasingly appearing in front of consumers, and have become one of the factors that influence consumers in considering a product to be purchased. Important messages must take precedence over holding consumers attractive and convincing them about the advertised product.

Expressed in Hemamalini \& Kurup (2014), that the message proves that there is a significant relationship with the effectiveness of advertising that influences purchase intentions. Framing positive messages must be used in advertising activities because they are more persuasive than negative messages. It was also said by Indriyanti \& Ihalauw (2002), that repeated advertising messages, influential in attracting attention, arousing interest, and encouraging consumers to make purchases. Advertising message is a very important component for consumers when viewing information about the quality of a product or service, and will be an 
Volume 8 Issue 7 July 2020

important reference in the process of purchasing decisions (Imbayani \& Gama, 2018).

This research discusses the effect of celebrity endorsement, message, and e-WOM on purchase intention of food and beverage on Instagram in millennial generation. (Hemamalini \& Kurup, 2014; Indriyanti \& Ihalauw, 2002; Imbayani \& Gama, 2018) have also studied this, but there are slight differences on the variables, the focus of the type of product, and the advertising media used. Then the similarity between this article and the journals above is on the research target of the millennial generation, and the use of messages in advertising. By looking at the results of previous studies regarding the effect of messages on purchase intention, the hypothesis 2 of this study is:

$\mathrm{H} 2$ : Message has a significant positive effect on purchase intention

\section{3 e-WOM}

$\mathrm{e}-\mathrm{WOM}$ is a form of marketing communication that contains positive or negative statements made by potential consumers, as well as former consumers about a product, which is available to many people through internet social media Thurau, et al., (2004). This understanding is used and continues to be developed in subsequent e-WOM studies such a (Zhang et al., 2009; Cheung \& Thadani, 2012; Kumadji \& Kusumawati, 2014) defining e-WOM is a statement put forward by potential consumers, actual, or former information about a product or service offered by a company via the internet.

Goyette et al., (2010) explain that e-WOM has 3 main characteristics, namely intensity, valence of opinion, and the content related to product or service. According to Qing \& Wattegama (2014), e-WOM occurs when there are people who intend to post their opinions and when there are people who want to seek opinions about a product or brand, where there are social relationships between them or are in the same age range, the same education, or the same social status. It was said by Wiridjati \& Roesman (2018), that along with the popularity of social media among the public, e-WOM began to become a source of information for influential products or services. In this discussion, what is influenced by e-WOM is consumer buying interest through Instagram social media.

e-WOM is able to influence the buying intentions of consumers (Sa'ait et al., 2016). This statement is supported by Hamidun \& Sanawiri (2018) which states that e-WOM has a significant effect on purchase intention. In addition, explained also by Imbayani \& Gama (2018), that e-WOM can have a positive impact in the form of increasing the effectiveness of marketing activities which increase buying interest and also negatively in the form of destroying a company's brand image. This opinion is also supported by Imbayani \& Gama (2018), which states that when they want to buy a product, they tend to concern other people's review and buying experience.

This research discusses the effect of celebrity endorsement, message, and e-WOM on purchase intention of food and beverage on Instagram in millennial generation. This was also examined by (Sa'ait et al., 2016; Hamidun \& Sanawiri, 2018; Imbayani \& Gama, 2018), but there were slight differences on the variables, and the focus of the type of product under study. Then for the similarity between this article and the journals above, the research target is the millennial generation, the media used for advertising is Instagram and lastly the use of e-WOM. By looking at the results of previous studies regarding the effect of e-WOM on purchase intention, the hypothesis 3 of this study is

H3: e-WOM has significant positive effect on purchase intention

\subsection{Purchase Intention}

Purchase intention is the tendency of personal actions related to the product (Bagozzi \& Burnkrant, 1979). This term is used and continues to be developed in subsequent purchase intention studies such as, the study of factors that affects purchase intention (Spears \& Singh, 2004; Shah, et al., 2012; Wang \& Tsai, 2014; Wang, et al., 2017), and in 2018 purchase intention was defined as the desire to choose a product or service needs (Patel \& Vaghela, 2018).

Setyawan \& Susila (2014) explained in their research about purchase intention that there are several things that are the main characteristics of purchase intention, namely the first intention as a link of motivational factors that influence a person's behavior. Second, intention describes the level of one's desire to try. Third, intention describes the size of expectations. Fourth, intention is related to sustainable action.

According to Lucas \& Britt (2012), there are several main things that make a person have buying interest, while in this research, the main thing that encourages buying interest in a person is feeling attracted to a product which in this case is a food and beverage product. As for fulfilling consumer interest, there are 
Volume 8 Issue 7 July 2020

various factors that can influence such as celebrity endorsement in the journal Fink et al., (2020); Abbas et al., (2018), message in the journal Arshad \& Aslam (2015); Hemamalini \& Kurup (2014) and e-WOM in the journal Tien et al., (2019); Dhanesh \& Duthler (2019); Sa'ait et al., (2016) which will be further investigated in this study as variables that influence purchase intention.

\subsection{Millennials}

According to Hady (2016), the millennial generation are those who were born in the early 1980s until 1999. From the National Socio-Economic survey data, it is said that as many as $33.75 \%$ of Indonesia's population are millennial. They were the first generation globally connected by the internet and social media. Now, social media has become a source for millennials to find any kind of information. This statement is supported by Haryanto (2019) who explains that millennials are the most internet users nowadays. This makes millennials rely on the internet as a tool to get information (Badan Pusat Statistik, 2018). The survey results from APJII show that more than $80 \%$ of millennials are active users of the internet (Haryanto, 2019).

Marketeers explained that millennial generation in Indonesia are the most potential buyer for online shopping compared to other generations because they are very active in using the internet and social media (Perdana, 2017). APJII research also shows that $11 \%$ of internet users in Indonesia make online transactions, and millennials are potential consumers of online shopping (Widiartanto, 2016). Therefore, this article focuses on the millennial generation in Indonesia, especially Jakarta.

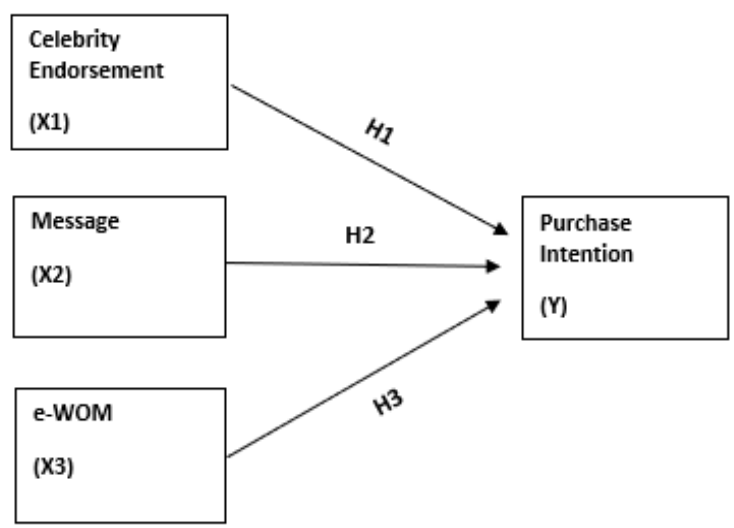

\section{METHODS}

Data for this study were collected during the 2020 pandemic through an online questionnaire (google form), used a convenience sampling method with a total sample of 130 people included in the millennial generation of Instagram users in Jakarta. The data processing method used in this study is Regression Analysis using IBM SPSS Statistic 22. The first step is to test the validity as evidence that shows that the instrument, technique, or process used to measure a concept, second performs a reliability test to measure the consistency of the respondent's answers, third classical assumptions test, and fourth conducted a correlation test to analyze the strength or weakness of the studied variables. After testing the classical assumptions, a regression test is performed to see the effect of the independent variables on the dependent variable.

From 130 respondents found that $33.1 \%$ were male and $66.9 \%$ were female, where $71.5 \%$ of respondents were domiciled in Jakarta. The whole respondent were the millennial generation whose age ranges from 20-29 years. It was also found that $51.5 \%$ of respondents had the last high school or vocational education, $37.7 \%$ were S1 and the rest were D3 10.8\%. Furthermore, as many as $53.1 \%$ of respondents were those who worked in formal companies, $35.4 \%$ of them were students, and $11.5 \%$ were entrepreneurs with employees. All respondents $(100 \%)$ have done online shopping where $35.4 \%$ of respondents shop online 1-2 times a month, $32.3 \%$ 3-4 times a month and the remaining $32.3 \%$ shop less than once in one month only. Product categories that have been purchased are F\&B as much as $100 \%$, hobbies $41.5 \%$, fashion $31.5 \%$, beauty products $23.1 \%$, and electronic products $22.3 \%$. The majority of food and beverage products purchased are in the form of finished products shipped.

In the first try of validity and reliability test, there were 3 indicators on the celebrity endorsement variable that are invalid so we re-do the test. Based on the results of the second data processing for the validity and reliability test, it can be concluded that all indicators and variables are declared valid and reliable. For other tests all indicators were in accordance with the regression test requirements. In simple regression testing the following results were obtained.

Figure 1: Theoretical Framework 
Volume 8 Issue 7 July 2020

\begin{tabular}{|l|c|l|}
\hline \multicolumn{2}{|c|}{ Table 1. Measurement } \\
\hline Measurement & Operational Variable & \multicolumn{1}{|c|}{ Source } \\
\hline Purchase Intention & Likert Scale & Wowor \& Lunarjanto, (2011) \\
\hline Celebrity Endorsement & Likert Scale & Magnini, honeycutt, \& cross (2008) \\
\hline Message & Likert Scale & Hemamalini \& Kurup, (2014) \\
\hline e-WOM & Likert Scale & Wiridjati \& Roesman, (2018) \\
\hline
\end{tabular}

\section{RESULT AND DISCUSSION}

Table 2. Result

\begin{tabular}{|c|cc|}
\hline Operational Variable & Mean Score & Standard Deviation \\
\hline Celebrity Endorsement & 35.0687 & 4.56945 \\
\hline Message & 9.8550 & 2.85043 \\
\hline e-WOM & 41.2519 & 2.01664 \\
\hline Purchase Intention & & 2.27649 \\
\hline
\end{tabular}

Table 3. Anova

ANOVA $^{\text {a }}$
\begin{tabular}{|c|c|c|c|c|c|}
\hline Model & Sum of Squares & df & Mean Square & f & Sig. $^{.006^{\text {b }}}$ \\
\hline Regression & 7.032 & 3 & 2.344 & 4.393 & \\
\hline Residual & 67.764 & 127 & .534 & & \\
\hline Total & 74.795 & 130 & & & \\
\hline
\end{tabular}

a. Dependent Variable: Purchase Intention

b. Predictors: (Constant), e-WOM, Celebrity Endorsement, Message

From the table above, we can find that celebrity endorsement, message and e-WOM have a significant effect on purchase intention. This can be seen from the significance value that is equal to 0.006 . So, it can be concluded that hypothesis 1 "Celebrity endorsement has a significant positive effect on purchase intention" is rejected, hypothesis 2 "Message has a significant positive effect on purchase intention" is accepted, and hypothesis 3 "e-WOM has significant positive effect on purchase intention" is accepted. 
Volume 8 Issue 7 July 2020

Table 4. Coefficients

Coefficients

\begin{tabular}{|c|c|c|c|c|c|c|}
\hline & \multirow[b]{2}{*}{ Model } & \multicolumn{2}{|c|}{ Unstandardized Coefficients } & \multirow{2}{*}{$\frac{\text { Standardized Coefficients }}{\text { Beta }}$} & \multirow[b]{2}{*}{$\mathrm{t}$} & \multirow[b]{2}{*}{ Sig. } \\
\hline & & B & Std. Error & & & \\
\hline \multirow[t]{4}{*}{1} & (Constant) & 5.118 & .733 & & 6.985 & .000 \\
\hline & $\begin{array}{l}\text { Celebrity } \\
\text { Endorsement }\end{array}$ & -.538 & .171 & -.271 & -3.158 & .002 \\
\hline & Message & .093 & .069 & .117 & 1.354 & .178 \\
\hline & e-WOM & .021 & .097 & .018 & .212 & .832 \\
\hline
\end{tabular}

a. Dependent Variable: Purchase Intention

From the SPSS calculation above, the results of the influence of celebrity endorsement (X1), message (X2), and e-WOM (X3) on purchase intention (Y) were found. Can be stated in the regression equation as follows:

$$
\mathrm{Y}=5.118-0.538 \mathrm{X} 1+0.093 \mathrm{X} 2+0.021 \mathrm{X} 3
$$

From the calculation of the table above it can be seen that,

- If the other variables are constant, the $\mathrm{Y}$ value will change by 5.118 .

- If the other variables are constant, the $\mathrm{Y}$ value will change by -0.538 per unit $\mathrm{X} 1$.

- If the other variables are constant, the Y value will change by 0.093 per unit X2.

- If the other variables are constant, the $Y$ value will change by 0.021 per unit X3.

The result for celebrity endorsement is not in accordance with the research of (Mubarok, 2016; Juliana et al., 2018; Abbas et al., 2018) which states that celebrity endorsement has a significant positive effect on purchase intention. In this case millennials tend to consider by the figure used for endorsement activities before buying a product, where if they do not like the figure or the figure is considered unattractive, it will negatively affect their buying interest, and if they have negative feelings toward a chosen celebrity, they are more likely to have negative feelings toward the endorsed brand as well (Han, et al., 2019). In case of message the result is in accordance with the research of (Hemamalini \& Kurup, 2014; Indriyanti \& Ihalauw, 2002; Imbayani \& Gama, 2018) which states that message has significant positive effect on purchase intention. Customers also consider the contents of messages or messages delivered by endorsers where even though they do not like the figures used, if the message content can be trusted and the messages conveyed are interesting, it can increase buying interest from customers. As for the e-WOM variable, the result is in accordance with the research of Sa'ait et al., 2016; Hamidun \& Sanawiri, 2018; Imbayani \& Gama 2018) who found that e-WOM has a significant and positive effect on purchase intention.

In this modern era, before buying a product online, customers certainly need to see reviews or ratings from previous buyers, especially millennials. The aim is to find out the quality of the item before buying it, the better the review and rating given to the product will attract buying interest and if the review of the product turns out to be poor, it will reduce the customer's buying interest for the item (IDN Research Institute, 2020). In this pandemic condition, it does not change the behavior of the customer towards celebrity endorsement, message and e-WOM because the customer still has a habit of shopping online. But with this pandemic situation online shopping activities will increase so that companies need to pay more attention to who the figure will be used as an endorser and control the messages and comments given in promotional activities. In addition, for further research, researchers can increase the number of respondents so as to increase the level of accuracy of the results of this study. Then subsequent studies can also expand the scope of the area of research and the scope of the target respondents to other generations.

\section{CONCLUSION AND RECOMMENDATION}

This article concludes that for the context of the sale of food and beverage products through Instagram on millennial generation in a pandemic situation, celebrity endorsement has a significant negative effect on purchase intention, while message and e-WOM have significant positive effect on purchase intention. In order to increase purchase intention in food and beverage products through Instagram, companies need to pay attention about the figure that will be used for 
Volume 8 Issue 7 July 2020

the promotional activities. Moreover, it is important to control the content of messages or messages delivered by endorsers. Lastly, companies need to take concern about comments given by other customers. The limitation of this article is that the samples used are only 130 and delivered only based on the Jakarta area. For further research to increase the accuracy level of study, researchers can add more numbers of respondents, expand the scope of the research area such as in big cities in Indonesia and expand to another generation.

\section{REFERENCES}

[1]. Curty, R. G., \& Zhang, P. (2012). Social commerce: Looking back and forward. Proceedings of the American Society for Information Science and Technology. United States: Wiley.

[2]. Das, K., Tamhane, T., Vatterott, B., Wibowo, P., \& Wintels, S. (2018). The digital archipelago: How online commerce is driving Indonesia's economic development. McKinsey\&Company.

[3]. Moriansyah, L. (2015). Pemasaran melalui Media Sosial: Antecedents and Consequences. Jurnal Fakultas Ekonomi dan Bisnis Universitas Indonesia, 187-196.

[4]. Atmoko, B. D. (2012). Instagram Handbook Tips Fotografi Ponsel. Jakarta: Media Kita.

[5]. Putri, A. R. (2019, Desember 24). Jumlah Pengguna Instagram di Indonesia Capai 61 Juta. From kumparan:

https://kumparan.com/kumparantech/jumlahpengguna-instagram-di-indonesia-capai-61-juta1sVVLzdQO0T/full

[6]. Amadea, A. (2018, November 6). William Wongso soal Tren Kuliner Medsos: Instagram Tak Bisa Kasih Rasa. From kumparan: https://kumparan.com/kumparanfood/william-wongsosoal-tren-kuliner-medsos-instagram-tak-bisa-kasihrasa-1541417593231175793/full

[7]. Wood, M. (2019, January 28). Retrieved from fundera.com: https://fundera.com/blog/instagramrestaurants

[8]. Khan, K. S., Rukhsar, A., \& Shoaib, M. (2016). Influence of Celebrity Endorsement on Consumer Purchase Intention. Journal of Business Management, 6-12.

[9]. Bovee, C. (1995). Advertising Excellence. United States of America: McGraw-Hill, Inc.

[10]. Sumartono. (2002). Terperangkap dalam Iklan: Meneropong Imbas Pesan Iklan Televisi. Bandung: Alfabeta.

[11]. Hemamalini, \& Kurup, S. K. (2014). Effectiveness Of Television Advertisement On
Purchase Intention. International Journal of Innovative Research in Science, Engineering and Technology, 9416-9422.

[12]. Saleh, R. (2017). Pesan Iklan dalam Membangun Merek. Jurnal Bisnis Terapan, 33-42.

[13]. Zhang, T., Omran, B. A., \& Cobanoglu, C. (2016). Generation Y's Positive and Negative E-Wom: Use of Social Media and Mobile Technology. Emerald Insight.

[14]. Thurau, H., T., K., Gwinner, \& GianFranco. (2004). Electronic Word Of Mouth Via Consumer Opinion Platforms: What Motivates Consumers to Articulate Themselves on the Internet. Journal of interactive Marketing, 38-52.

[15]. Permadi, P. C., Kumadji, S., \& Kusumawati, A. (2014). PENGARUH CITRA MEREK TERHADAP WORD OF MOUTH DAN KEPUTUSAN PEMBELIAN (Survei pada Konsumen Dapoer Mie Galau Jalan Selorejo 83 Malang). Jurnal Administrasi Bisnis, 1-7.

[16]. Abubakar, A. M., \& Ilkan, M. (2016). Impact of Online WOM on Destination Trust and Intention to Travel. A Medical Tourism Perspective. Journal of Destination Marketing\&Management, 192-201.

[17]. Sa'ait, N., Kanyan, A., \& Nazrin, M. F. (2016). The Effect E-WOM on Customer Purchase Intention. International Academic Research Journal of Social Science, 73-80.

[18]. Khan, M. M. (2018). The Effect of Celebrity Endorsement on Consumer Purchase IntentionEvidence from Q-Mobile Linq Advertisement. Pakistan Business Review, 1065-1082.

[19]. Abbas, A., Afshan, G., Aslam, I., \& Ewas, L. (2018). The Effect of Celebrity Endorsement on Consumer Purchase Intention: A Comparative Study. Current Economics and Management Research, 1-10.

[20]. Imbayani, I. A., \& Gama, A. W. (2018). The Influence of Electronic of Mouth (E-Wom), Brand Image, Product Knowledge on Purchase Intention. Jurnal Ekonomi dan Bisnis Jagaditha.

[21]. Wiridjati, W., \& Roesman, R. R. (2018). Fenomena Penggunaan Media Sosial dan Pengaruh Teman Sebaya pada Generasi Milenial terhadap Keputusan Pembelian. Jurnal Manajemen dan Pemasaran, 275-290.

[22]. McCracken, G. (1989). Who is the celebrity endorser? Cultural foundation of the endorsement process. Journal of Consumer Research, 310-321.

[23]. Shimp, T. (2000). Advertising, Promotion \& Supplemental Aspects of Integrated Marketing Communications. New York: Dryden Press.

[24]. Patra, S., \& Datta, S. (2010). Celebrity 
Volume 8 Issue 7 July 2020

endorsement in India--emerging trends and challenges. Journal of Marketing \& Communication, 16-23.

[25]. Karasiewicz, G., \& Kowalczuk, M. (2014). Effect of Celebrity Endorsement in Advertising Activities by Product Type. International Journal of Management and Economics, 74-91.

[26]. Dewi, Y. R. (2017). Pengaruh Celebrity Endorsement terhadap Brand Credibility dan Brand Equity pada Online Shop (Study pada Online Shop Vanilla Hijab Indonesia). Ekonomi Bisnis, 80-86.

[27]. Mowen, C., John, \& Minor, M. (2002). Perilaku Konsumen. Jakarta: Erlangga.

[28]. Rossiter, J., \& Percy, L. (1998). Advertising Communication and Promotion Management. Singapura: McGraw-Hill Inc.

[29]. Mubarok, D. A. (2016). Pengaruh Celebrity Endorsement terhadap Minat Beli Konsumen (Studi pada Konsumen Mahasiswa Kelas Regular Sore STIE INABA Bandung). Jurnal Indonesia Membangun.

[30]. Pringle, H., \& Binet, L. (2005). How marketers can use celebrities to sell more effectively. Journal of Consumer Behaviour.

[31]. Schluschen, A. (2016). Celebrity Endorsement in Social Media. Germany: IGI Global PUBLISHER of TIMELY KNOWLEDGE.

[32]. Juliana, Djakasaputra, A., Hubner, I. B., \& Noval, T. (2018). Pengaruh Celebrity Endorser dan Brand Image terhadap Purchase Intention Produk Kosmetik Etude House pada Mahasiswi Sekolah Tinggi Pariwisata Pelita Harapan Karawaci. Jurnal Ilmiah Skylandsea, 251-256.

[33]. Indriyanti, I. S., \& Ihalauw, J. J. (2002). Pengulangan Pesan Suatu Iklan dalam Proses Pembelajaran Konsumen. Jurnal Ekonomi dan Bisnis.

[34]. Jansen, B. J., Zhang, M., Sobel, K., \& Chowdury, A. (2009). Twitter Power: Tweets as Electronic Word of Mouth. JOURNAL OF THE AMERICAN SOCIETY FOR INFORMATION SCIENCE AND TECHNOLOGY, 2169-2188.

[35]. Cheung, C., \& Thadani, D. (2012). The Impact of Electronic Word-of-Mouth Communication: A Literature Analysis and Integrative Model. Decision Support System, 461-470.

[36]. Goyette, I., Ricard, L., Bergeron, J., \& Marticotte, F. (2010). e-WOM Scale: Word-of-Mouth Measurement Scale for e-Services Context. Canadian Journal of Administrative Sciences, 5-23.

[37]. Qing, P., \& Wattegama, W. (2014). Effect of eWOM on Buying Intention for a Crisis Product: A Theoretical Reflection. Journal of Management 5, 3747.

[38]. Hamidun, M. A., \& Sanawiri, B. (2018).
Pengaruh Electronic Word of Mouth terhadap Purchase Intention melalui Brand Image (Studi pada Followers Akun Instagram @Ouvalresearch). Jurnal Administrasi Bisnis.

[39]. Bagozzi, R. P., \& Burnkrant, R. E. (1979). Attitude organization and the attitude-behavior relationship. Journal of Personality and Social Psychology, 913-929.

[40]. Spears, N., \& Singh, S. (2004). Measuring attitude toward the brand and purchase intentions. J. Curr. Issues Res Advert.26 (2), 53-66.

[41]. Shah, e. (2012). "Factors Affecting Pakistan's University Student's purchase intention towards foreign apparel brands". Journal of Management vol $17,1-14$.

[42]. Wang, Y.-H., \& Tsai, C.-F. (2014). The Relationship Between Brand Image and Purchase Intention: Evidence From Award Winning Mutual Funds. The International Journal of Business and Finance Research, Vol. 8 No. 2.

[43]. Wang, S., Kao, G. H.-Y., \& Ngmiriudom, W. (2017). Consumers' Attitude Of Celebrity endorser, Brand and Intention With Respect to Celebrity Endorsement of The Airline Sector. Journal Of Air Transport Management.

[44]. Patel, H. R., \& Vaghela, P. S. (2018). Proposed Theoretical Framework for Predicting Green Purchase Intention of Consumers: An Extended Theory of Planned Behaviour. International Journal of Creative Research Thoughts, 244-254.

[45]. Setyawan, A., \& Susila, I. (2004). Pengaruh Service Quality Perception Terhadap Purchase Intention. Usahawan NO. 07 TH XXXI11 JULI 2004.

[46]. Lucas, D., \& Britt, S. (2012). Measuring Advertising Effectiveness. New York: McGraw-Hill.

[47]. Fink, M., Koller, M., Gartner, J., Floh, A., \& Harms, R. (2020). Effective entrepreneurial marketing on Facebook - A longitudinal study. Journal of Business Research, 149-157.

[48]. Arshad, S., \& Aslam, T. (2015). The Impact of Advertisement on Consumer's Purchase Intentions. SSRN Electronic Journal.

[49]. Tien, D. H., Rivas, A. A., \& Liao, Y.-K. (2019). Examining the influence of customer-tocustomer electronic word-of-mouth on purchase intention in social networking. Asia Pacific Management Review, 238-249.

[50]. Dhanesh, G. S., \& Duthler, G. (2019). Relationship management through social media influencers: Effects of followers' awareness of paid endorsement. Public Relations Review, 1-13.

[51]. Hady, Y. (2016, January 17). Millennial 
Volume 8 Issue 7 July 2020

Trends 2016. Retrieved from Yuswohady.com: https://www.yuswohady.com/2016/01/17/millennialtrends-2016/

[52]. Haryanto, A. T. (2019, Mei 16). Pengguna Internet Indonesia Didominasi Milenial. Retrieved from detikInet: https://inet.detik.com/telecommunication/d4551389/pengguna-internet-indonesia-didominasimilenial

[53]. Badan Pusat Statistik. (2018). STATISTIK GENDER TEMATIK: PROFIL GENERASI MILENIAL INDONESIA. Jakarta: Kementerian Pemberdayaan Perempuan dan Perlindungan Anak.

[54]. Perdana, J. (2017, December 31). Delapan Tren Marketing di Indonesia Pada Tahun 2018. Retrieved https://marketeers.com/delapan-tren-marketing-diindonesia-pada-tahun-2018/

[55]. Widiartanto, Y. H. (2016, Oktober 24). 2016, Pengguna Internet di Indonesia Capai 132 Juta. Retrieved from KOMPAS.com: https://tekno.kompas.com/read/2016/10/24/15064727/ 2016.pengguna.internet.di.indonesia.capai.132.juta [56]. Han, J., Min, J., Jung, H., Chang, J., Min, T., Jai, C., et al. (2019). The effects of celebrity-brand congruence and publicity on consumer attitudes and buying behavior. Asia Pacific Journal of Management. [57]. IDN Research Institute. (2020). Indonesia Millennial Report 2020. Jakarta: IDN Media. 